\title{
The role of water vendors in water service delivery in developing countries: a case of Dala local government, Kano, Nigeria
}

\author{
Muhammad Tajuri Ahmad ${ }^{1}$
}

Received: 20 December 2013/ Accepted: 22 November 2016/Published online: 3 December 2016

(C) The Author(s) 2016. This article is published with open access at Springerlink.com

\begin{abstract}
In Nigeria, more than 60 million people are required to meet Millennium Development Goals (MDGs) target for improved water by 2015 and is unlikely to be achieved only by public supply. To cover these water availability gaps water vendors exist and ignoring their role is potentially deceptive. The aim of this paper is to assess the role of water vendors in meeting these peoples' need and elicit household's willingness-to-pay for improved supply. The research includes cross-sectional mixed method in which questionnaire survey was performed to 218 households; and interviews and focus group discussion were conducted with water vendors. Findings reveal that water vendors supplied most households irrespective of season. Retail vendors buy 251 at $\$ 4.00$ (\$0.013) from wholesale vendors and resale at $\$ 20.08$ (\$0.07) during dry and at 14.02 (\$0.05) in wet season. The price is 28 and 40 times the cost of in-house connection from Kano State Water Board (KNSWB) during rainy and dry season, respectively. Vendors who buy from hand-dug wells pay $\$ 100.00$ (\$0.33) per day and draw as much water within that day. Furthermore, willingness-to-pay for in-house connection was elicited as $\$ 367.00$ (\$1.20), lower than monthly flat fixed tariff set by KNSWB. The study recommends recognizing vendors formally in form of public private partnership so that technical and financial support be given, thus their activities and charges be regulated. People's perception on water should be changed through education and enlightening. Further research should focus
\end{abstract}

Muhammad Tajuri Ahmad amtajuri@yahoo.co.uk

1 Civil Engineering Department, Faculty of Engineering, Kano University of Science and Technology, Wudil, Kano, Nigeria on estimating total volume of water supplied by water vendors.

Keywords Water vendors · Nigeria Low income $\cdot$ Water supply · Households · Willingness-to-pay

\section{Introduction}

Increasing access to improved drinking water is part of Millennium Development Goals (MDGs) adopted by Nigeria and other nations worldwide. About one-tenth of world population - a total of 700 million people-remain without access to improved drinking water, while 2.5 billion lack basic sanitation with nearly half living in subSaharan Africa and one-fifth in Southern Asia (WHO/ UNICEF 2015). Access to water of sufficient quantity and acceptable quality remains one of the major problems for many households in most cities of developing countries especially in low income areas (Kjellen 2000; Acey 2008; Sansom and Bos 2008; Abubakar 2016). In Nigeria and Kano more than 60 million people (40\%) and 3 million (30\%) are required to meet MDGs target for improved drinking water supply, respectively (National Population Commission-NPC and ICF 2014).

To cover this inadequacy in water provision by public utilities in many cities, alternative suppliers exist such as non-state water providers (NSPs) including both formal and informal local private providers commonly known as water vendors. Historically, water vending is an old practise world over. In previous literatures, proper discussion was done on definitions, conceptions, operations and some challenges related to water vending in developing countries from different perspective (Zaroff and Okun 1984; Snell 1998; Njiru 2004; Kjellen and McGranahan 2006; Sansom 
and Bos 2008; Opryszko et al. 2009; Wutich and Brewis, 2014; Wutich et al. 2016). One of the features of water vendors is that they can be unionized (which help them self-regulate water prices, monitor the quality of water distributed, and innovate improved services) or nonunionized (Wutich et al. 2016) which is the case in many low income areas.

Water vending tends to be an integral part of water supply system in developing countries especially in poorer, low income or informal settlements (Whittington et al. 1991; Snell 1998; Opryszko et al. 2009; Ishaku et al. 2010; Olajuyigbe et al. 2012; Onyenechere et al. 2012; Ayalew et al. 2014) although vendors can be found in wealthier areas (Kjellen 2000). Water resources for vendors may differ in space and time, for example, in Ethiopia it is primarily from municipal supply system while in Kenya vendors sell from a combination of municipal supply and privately owned boreholes and wells (Ayalew et al. 2014). The mode of distributions may be home deliveries (by distributing vendors) using hand-carried, donkey carts, pushcarts or tank trucks, or at reselling stations (from which consumers collect water) (Kjellen 2000; Nigerian Industrial Standard 2007). In terms of coverage, it varies enormously between season and at different areas, for example, most households in Nsukka rely almost exclusively on water vendors (Onyenechere et al. 2012) and get worst as rain recedes (Nnaji et al. 2013) while it was only $3.8 \%$ covered by vendors in Kisumu (Ayalew et al. 2014).

Besides water-related diseases associated with informal water vendors (Olajuyigbe et al. 2012; Kjellen and McGranahan 2006; Hutin et al. 2003), it is often more expensive resulting in households already paying more than the stipulated bills charged by public utilities (Kjellen 2000; Ishaku et al. 2010; Dauda et al. 2015; Rahaman and Ahmed 2016). This was attributed to the lack of access to subsidies that would cover their initial investments and operating cost (Opryszko et al. 2009), and then blaming on governance (Njiru 2004). Another problem caused by vendors is the risk of increased traffic accidents (Kjellen 2000). Some problems bedevilling water vending include lack of recognition and regulation by government. It is of no doubt that recognizing them as part of a regulatory framework will assist in the realisation of MDGs target (Njiru 2004; Ayalew et al. 2014) while safeguarding extensive surveillance will ensure safety (Ishaku et al. 2010; Sheshe and Magashi 2014).

Water vending plays an important role to the extent that Wutich et al. (2016) concluded that it helps in advancing the human right to water, and services a significant number of households (van Dijk 2008; Nnaji et al. 2013) besides sustaining the livelihoods of many young people (Kjellen 2000). Water vending was once seen as an undesirable but temporary solution (Zaroff and Okun 1984; Kjellen 2000), later on as a coping strategy (Kjellen and McGranahan 2006; Olajuyigbe et al. 2012) but now is increasingly viewed as a necessary and acceptable path to achieving the MDGs target (McGranahan et al. 2006; Wutich et al. 2016).

In previous literature, households were selected using snowball (Kjellen 2000; Ayalew et al. 2014) and systematic random sampling procedure (Kjellen 2000), while in others stratified sampling (Ishaku et al. 2010) and simple random sampling (Nnaji et al. 2013; Onyenechere et al. 2012) were adopted.

Until now, little work has been done to understand and evaluate the operational capacity of water vendors and ascertain their contribution to Kano water supply. Previous studies were mainly on water quality; physicochemical and microbiological (see for, e.g., Sheshe and Magashi 2014). Thus, the objective of this study is to assess the role of water vendors in providing water supply in Dala LGA with a view to understand and evaluate their operational capacity. Investigating household's willingness-to-pay for improved water supply services constitutes a secondary objective of the study. Dala LGA was selected as the case study because of its population and being home to a large number of water vendors in Dandinshe area called Duniyar Yangaruwa (water vendor's world). The study will contribute in addressing some of fundamental questions like; How do informal water vendors operate and to what extent? Are households paying more for water? The study will only focus on distributing water vendors who carry water in plastic jerry-cans loaded onto pushcarts.

\section{Materials and methods}

\section{Study area}

Dala local government area (LGA) (Fig. 1) is the second most populated local government in Kano state having an estimated population of 418,759 people living in 68,005 households (NPC 2010) occupying an area of $1482 \mathrm{~km}^{2}$. It is bounded to the west by Ungogo, to the southwest by Gwale, to the southeast by Municipal, to the east by Nassarawa and to the north by Fagge. It has 11 wards namely; Bakin Ruwa, Dala, Dogon Nama, Gobirawa, Gwammaja, Kabuwaya, Kantudu, Kofar Mazugal, Kofar Ruwa, Madigawa and Yalwa. It lies between latitude $12^{\circ} 00^{\prime}$ to $12^{\circ} 03^{\prime} \mathrm{N}$ and longitudes $8^{\circ} 3^{\prime}$ to $8^{\circ} 05^{\prime} \mathrm{E}$. Kano experiences four distinct seasons, Rani (warm and dry), Damina (wet and warm), Kaka (cool and dry) and Bazara (hot and dry) closely associated with the movement of the Inter Tropical Discontinuity (ITD) zone. The mean annual rainfall is about $884 \mathrm{~mm}$ while mean annual temperature ranges from 26 to $32{ }^{\circ} \mathrm{C}$ and relative humidity of $17-90 \%$ (Olofin 


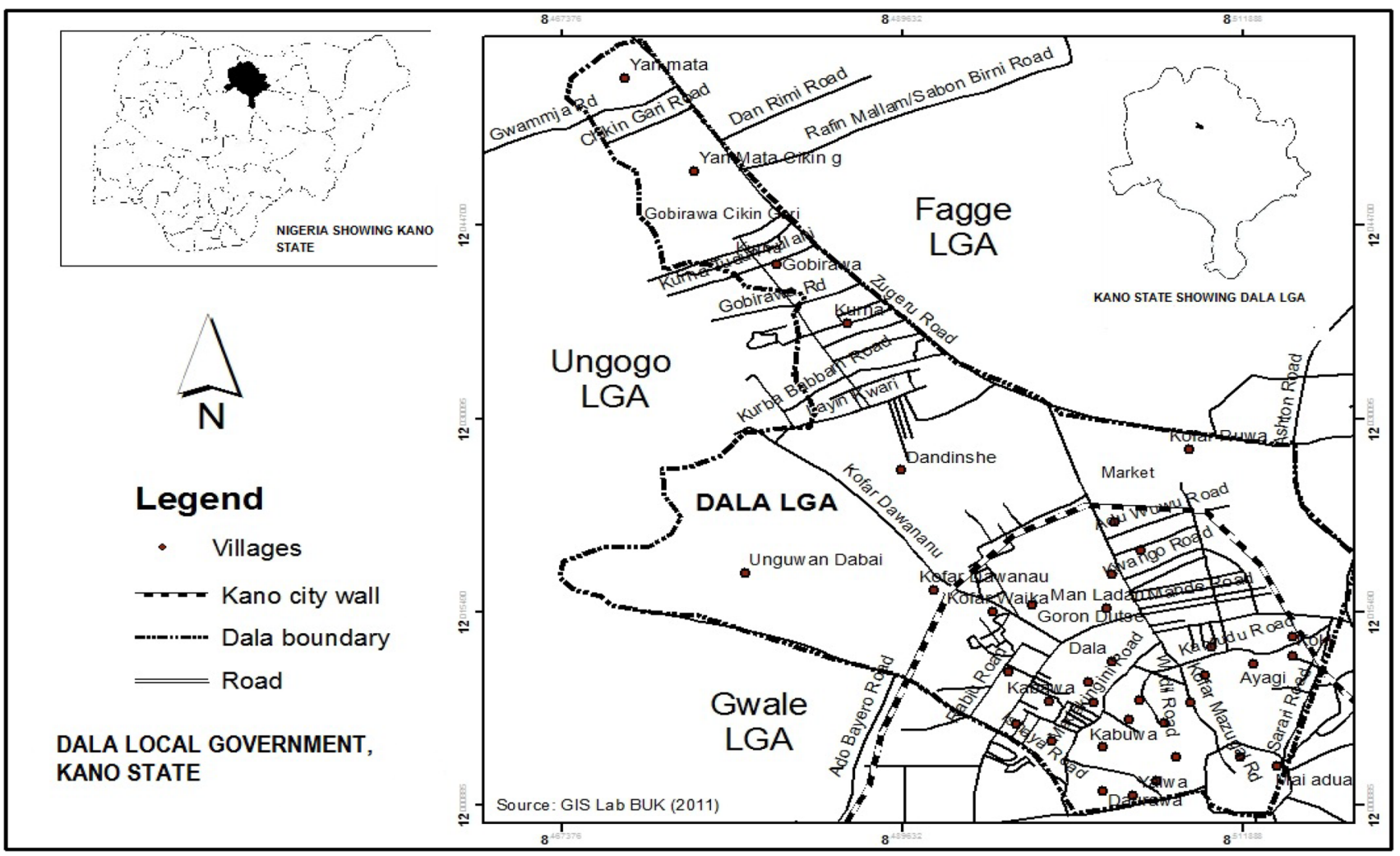

Fig. 1 Map of Dala local government area.Source: GIS Laboratory Bayero University Kano

1987). The study area is part of Kano Metropolis (among the eight metropolitan local governments of Kano state) and the water vendors serve not only the study area but also adjacent areas. It is important to note that Dala has predominantly mixed development where poor and non-poor live close together as a result of its history and general lack of urban planning.

There is a place in Dandinshe (see Fig. 1) known and found to have a large number of water vendors called Duniyar Yangaruwa (water vendor's world). During dry season of every year migrants from neighboring states and countries come to carry water vending business. There are higher concentrations of private commercialized boreholes and hand-dug wells in the area. It is important to note that for the purpuse of this study, retail vendors refer to mobile water distributors who carry water to the premises of the end-consumers (households) and wholesale vendors refer to those who sell to retail water vendors at a selling point.

\section{Data collection and analysis}

This research employed cross-sectional mixed method because while households participated in questionnaire survey without any reservation, water vendors especially retail vendors were not feeling free to participate due to the nature of informal activities related to water vending, and majority are non-indigenes living without proper documentation. To ensure the validity and reliability of the results to be obtained, the study employed method based on several other studies (Kjellen 2000; Nnaji et al. 2013; Ayalew et al. 2014; Wutich et al. 2016) as recommended in Galvin (2015). A reconnaissance survey of Duniyar Yangaruwa (water vendor's world) was carried out in June 2009 to be familiar with the environment and personals that operate hand-dug wells, water kiosk and the water vendors. The questionnaire was then constructed and pre-tested during a pilot study and answers were evaluated. It was then restructured to adapt better to the target respondents. The questionnaire consisted of 22 questions in 3 sections. The first section dealt with socioeconomic and demographic characteristics (e.g., age, household size, monthly income, etc.). Second section dealt with household water resources, quantity of water used, price of vended water, perception of water quality, etc.). The last section dealt with willingness-to-pay for improved services. The data were collected from July to October 2009 by the researcher and two enumerators.

The research population is the total number of households and water vendors in Dala LGA. There are 11 wards and considering the heterogeneity of the population, it was stratified for sampling based on the existing wards. Five wards were randomly selected for the study on the

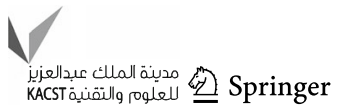


Fig. 2 Age distribution of respondents

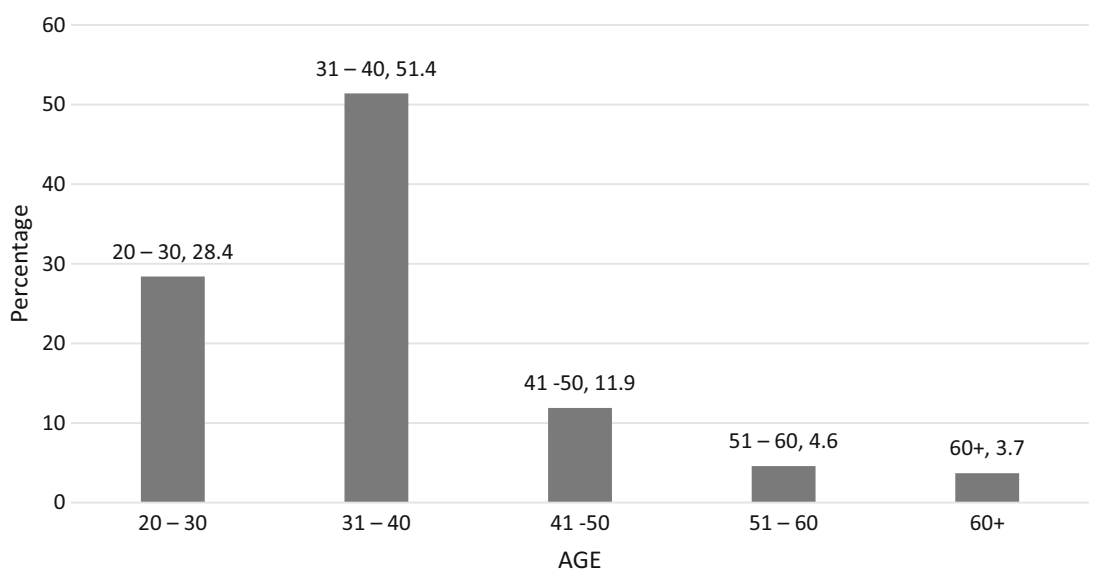

assumption that each ward has equal population. A simple random sampling technique was adopted in the selection of households in each ward. Due to limited resources, 250 questionnaires were administered to the households. Two hundred and eighteen completed responses were used and the rest (32) were discarded due to obvious inconsistencies in the respondents' answers. The 250 questionnaires were administered to the head of the selected households and every details explained to them and were left with the literate respondents for a minimum of 3 days to allow adequate time for filling. For the illiterate ones, the researcher and two enumerators had to fill the questionnaires in accordance with responses from them using the native language, Hausa. Before initial data screening all the returned questionnaires were coded and entered in Excel software. The variables were measured using five-point Likert scale.

In addition to the information from household surveys, information was also obtained from water vendors through structured interviews that took place at Duniyar Yangaruwa (water vendor's world) and the neighboring places where water vendors are found. It took place concurrently with the household survey. Interviews were conducted with 20 retail and 10 wholesale vendors. Respondents were recruited randomly at water collection points while queuing, and in some cases through word of mouth as employed in Wutich et al. (2016) based on their acceptability to participate because they tend to be very sceptical about interviews. Vendors were asked about water sources, water quality, water price, average time spent queuing, number of trips made daily and distance to the sales point. Focus group discussion (FGD) with the researcher and 5 wholesale vendors were then conducted at a water kiosk and then with five (5) retail water vendors at Duniyar Yangaruwa separately in November 2009. Discussion was recorded using paper and pencil. Between 2009 and now, the dollar exchange rate has gone up considerably (almost doubled) though there are no appreciable price differences of vended water between the two periods. Spot checks on sales prices were made to verify this. Nevertheless, the current rate of \$305 per US\$ is used where dollar equivalents are given in the text.

\section{Results and discussion}

\section{General household characteristics}

Variables such as socioeconomic and demographic play an important role in affecting the responses of households. In this study area, majority of household heads are male (94\%) and female constituted only $6 \%$, while $75 \%$ had at least some formal education whereas $25 \%$ had no formal education. Figures 2 and 3 show the age distribution and educational level of the respondents. The average household size was found to be nine members (Fig. 4 shows the percentage of the household sizes). Although residents in Dala LGA live in heterogeneous clusters combinations of high and low income earners of varied occupations in the same vicinity, majority of respondents could be considered low income (poor) because the average monthly income was $\$ 9750$ (\$32) which is below minimum wage of $\$ 18,000$ (\$59) prescribed by the government for civil servants in Nigeria. Figures 5 and 6 show various monthly income levels and employment status of the respondents, respectively.

Seasonal variation influences the means of water collection in the study area such that during dry season most households $(70.1 \%)$ depend on water vendors as their primary water source while $22 \%$ obtained water from public boreholes. Only small proportions depend on in-house connection from KNSWB (3.2\%) and well (4.7\%). Similarly, during wet season large percentage depend on rain water $(44.8 \%)$ and water vendors $(44 \%)$ and the rest depend on other sources such as in-house connection from KNSWB (4.1\%), public borehole (5\%) and wells $(2.1 \%)$. Thus, overwhelmingly the water used by households 
Fig. 3 Educational level of respondents

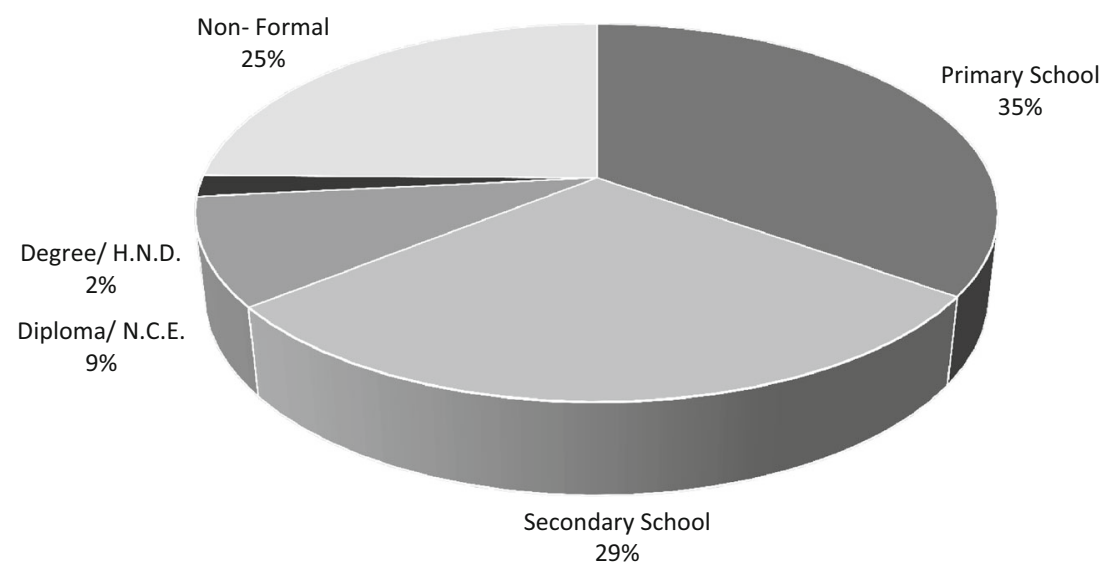

water free in the form of charity; they do not resell it as it was commonly found in southern part of Nigeria (Olajuyigbe et al. 2012; Onyenechere et al. 2012) or other parts in developing countries (Kjellen and McGranahan 2006).

\section{Water vending in Dala LGA}

The predominant vendors in the study area are retail water vendors who distribute water door-to-door to households with pushcarts. Of the retail vendors interviewed, most are young men with little or no formal education commonly from Niger Republic, although Nigerians were found. They buy water from water kiosk using a pushcart carrying 12 or 20 number of 251 jerry-cans. The pushcarts had motorcycle tyres. White or yellow or black cans were used although customers preferred black cans because they said it was bigger in terms of quantity. It was revealed that majority of them $(85 \%)$ hire the set (cart with the jerry-cans) at the rate of $\$ 100$ (\$0.33) and $\$ 150$ (\$0.49) per day for 12 and 20 jerry-can carrying cart, respectively. The maximum trips a vendor can have in a day was 3 due to long queue (average queuing time was $6 \mathrm{~h}$ ) encountered in almost all the Water kiosks and distance to the delivery point. Figure 7 shows pushcarts on que waiting for their turns. Vendors complained on the difficulty of conveying the filled pushcart to

Fig. 5 Monthly income level of household heads (Naira) (1 USD $=305$ Naira $(N)$ at the date of 30 September 2016)

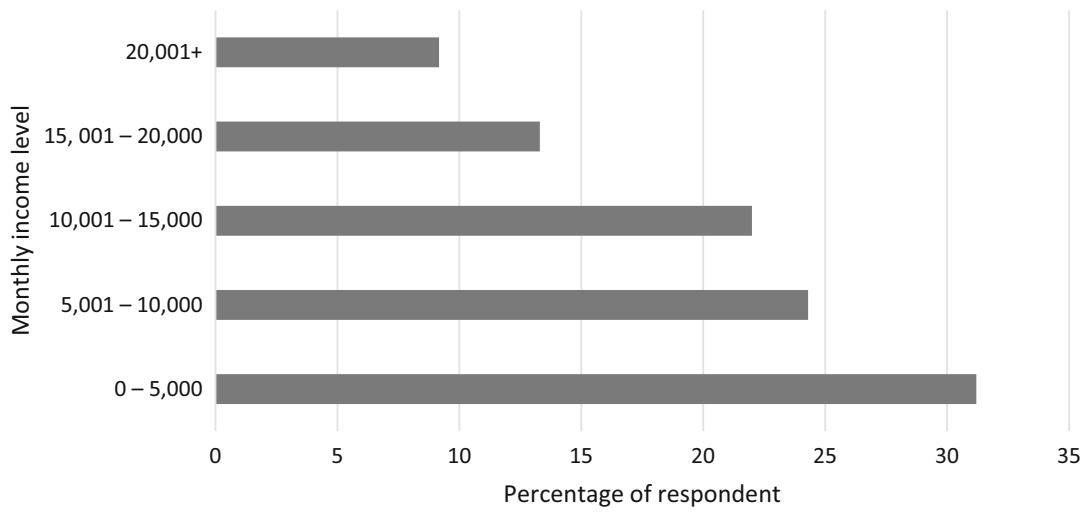


Fig. 6 Employment status of respondents

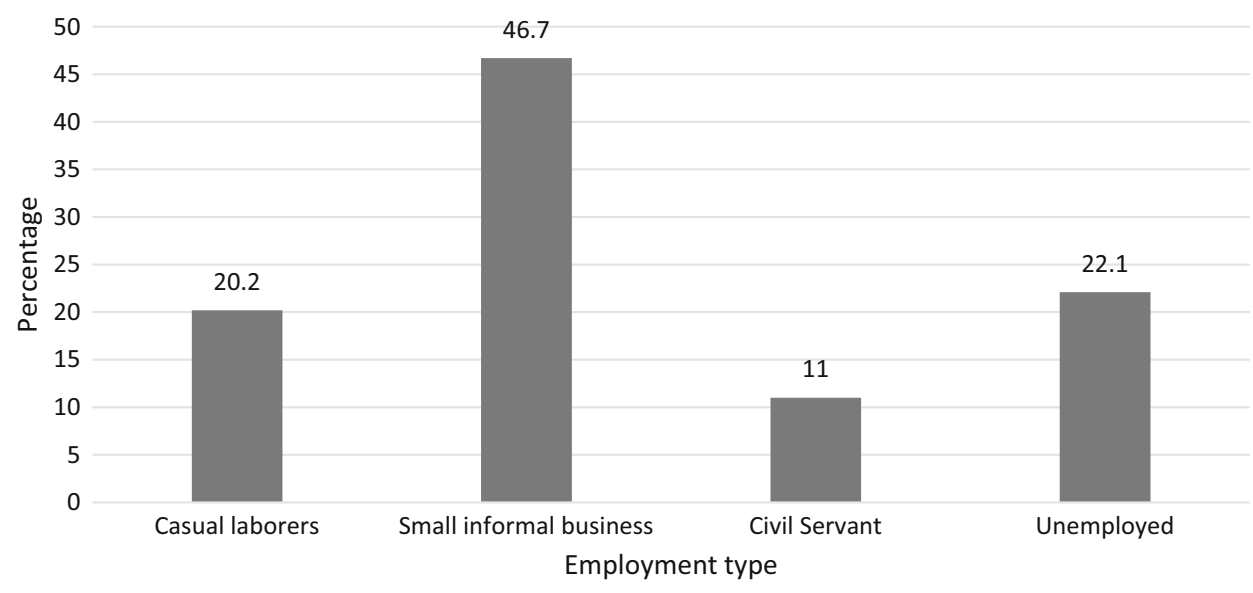

Table 1 Water resources during wet and dry seasons in Dala LGA

\begin{tabular}{lll}
\hline Water resources & $\begin{array}{l}\text { \% of households } \\
\text { (dry season) }\end{array}$ & $\begin{array}{l}\text { \% of households } \\
\text { (rainy season) }\end{array}$ \\
\hline $\begin{array}{l}\text { In-house connection } \\
\text { from KNSWB }\end{array}$ & 3.2 & 4.1 \\
$\begin{array}{l}\text { Rainwater } \\
\text { Public borehole }\end{array}$ & 0 & 44.8 \\
Water vendor & 22.0 & 5 \\
Well & 70.1 & 44 \\
Total & 4.7 & 2.1 \\
\hline
\end{tabular}

delivery points which they considered as the toughest part of the job because of the nature of roads and the distances. A load of twelve and twenty 25-1 jerry-cans weights 300 and 500 kilos, respectively, to which must be added the weight of the pushcart. Vendors revealed that most of the accidents caused by pushcarts were as a result of losing control by the vendor due to the heavy nature of the pushcart when filled.
Of the ten wholesale vendors interviewed, none of them had any agreement with the KNSWB to sell water (after all the water is from borehole not from KNSWB, so they said) and their activities are not being monitored by government or any agency except for the revenue collected by local government authorities. Therefore, management of water vending remains an individual business managed by the respective owners and water and financial management lie with the individual vendor. There are normally an average of two staffs (all male) overseeing the smooth running of the water kiosk-a manager and operator(s) of the tapsthe former collects all monies and the latter operate the system. Normally it is operated for more than $14 \mathrm{~h}$ daily starting from four o'clock in the morning.

\section{Water sources and quality}

Wholesales water vendors sell water from privately owned commercialized boreholes popularly known as Water kiosk (Gidan Ruwa) and not from piped distribution from KNSWB as it was the case in Kjellen (2000) where majority of vendors

Fig. 7 Pushcarts on queue

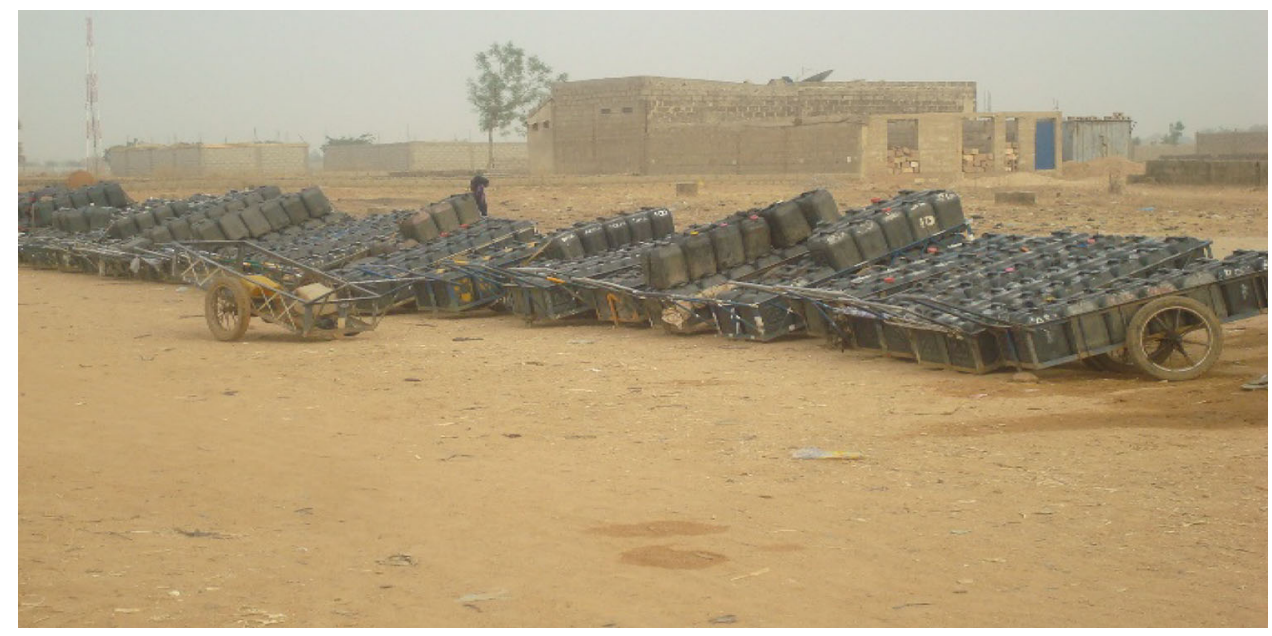


further distribute water initially supplied by public utility. Typical water system consists of one or more deep wells with a submersible pump and 50001 GeePee tanks often fixed in the yard on a concrete platform. All the water kiosks used lister type diesel generator. Tanks range from 2 to more than 6 in some water kiosk, but can be less than in some instances. Taps are connected to the tanks and fixed on the outer wall from where the vendors queue to wait for their turns (where there is a fence, otherwise just on the platforms) as can be seen in Fig. 8. In some water kiosk, underground storage tank with an average size of $2.5 \times 2.5 \times 3$ meters is constructed within the yard. The interior is plastered with cement and an opening of about $0.5 \mathrm{~m}^{2}$ is made at the top where water is drawn from the reservoir (Fig. 9). In other water kiosk 33,000 1 tank (initially petroleum tanker) was used to store water and sell to costumers instead of GeePee tanks as can be seen in Fig. 10. Apart from water kiosk there were also a significant number of hand-dug wells scattered all over $\mathrm{Du}$ niyar Yangaruwa that had sold water to vendors and some neighboring households as can be seen in Fig. 11. It was gathered during the survey that people dug wells on plot of lands to sell water and hence the high number of these kind of wells. In many cases, however, the vendors buy from both sources. The choice of water source would mostly depend on distance and to some extent on quality (whether soft or hard water). Hard water (Ruwan zartsi) is generally cheaper than soft water (Ruwan dadi). No Water kiosk was found to have been supplied with water from private water tankers.

Generally, there is lack of water quality awareness among many water vendors; their perception on water quality is typically assessed by observing color, odor and taste of water. Thus, the quality of vended water is questionable in the study area-as it is the case in many parts of the worldleading to water-related disease. The commonly reported water-related diseases by respondents in the study area were stomach ache (4.6\%); cholera (1.8\%); diarrhea (4.6\%); typhoid (25.7\%) and malaria (49.5\%). Only $13.8 \%$ have not been affected with one or more water-related diseases in the

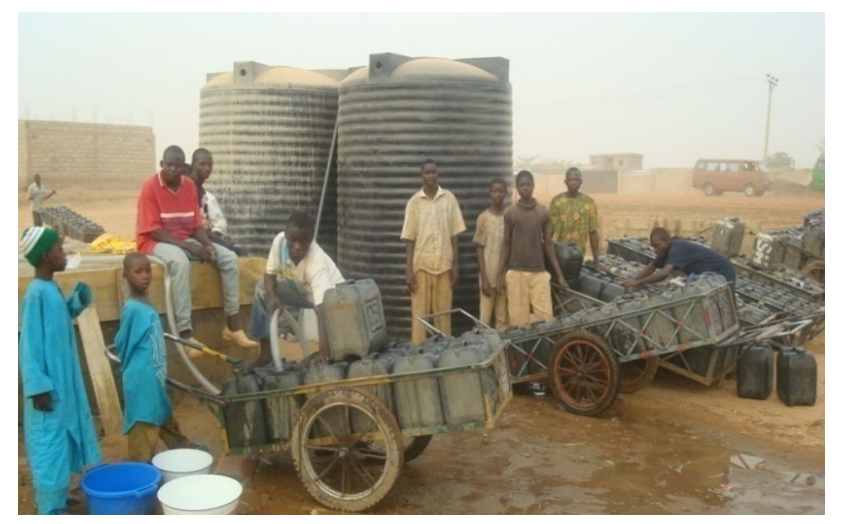

Fig. 8 Typical water kiosk

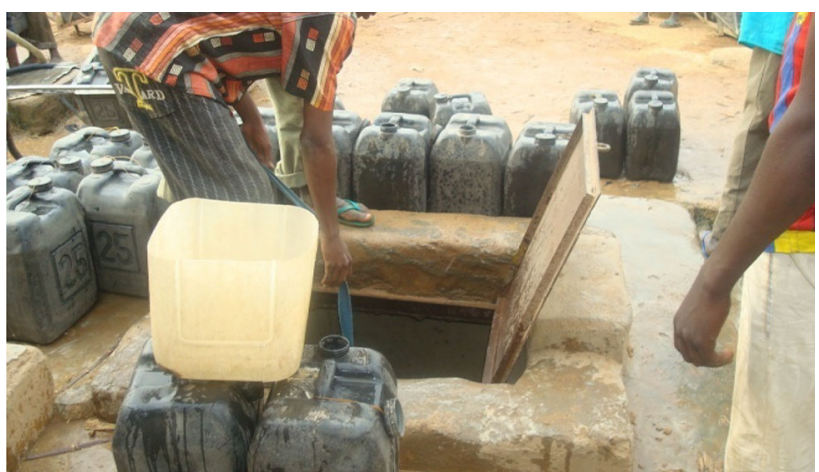

Fig. 9 Underground storage tank

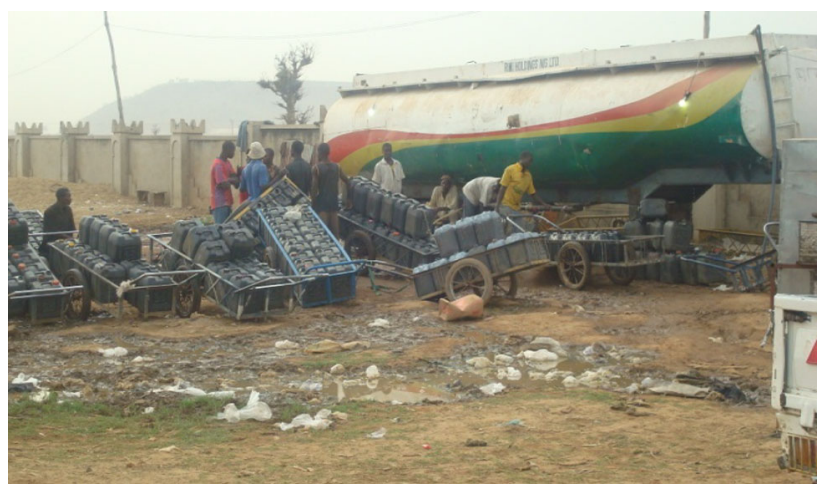

Fig. 1033,0001 tank storage

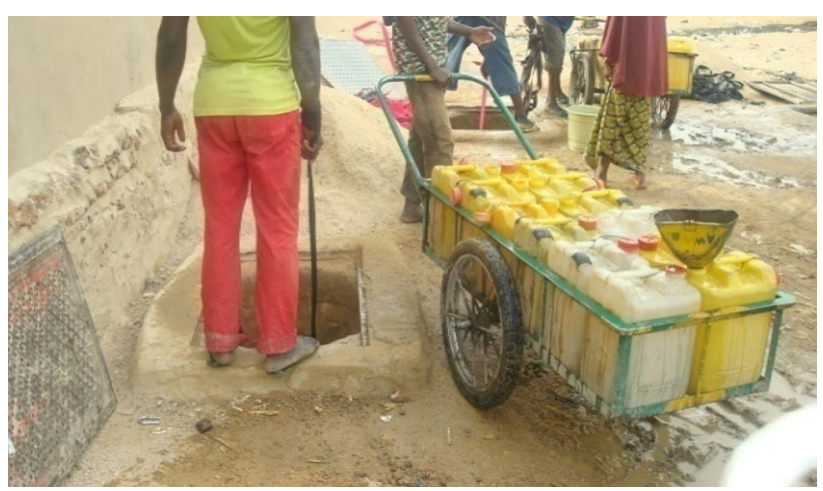

Fig. 11 Commercialized hand-dug wells

recent time (Fig. 12). It is obvious that this high incidence of diseases is related to the fact that vended water is usually unsafe since it is commonly susceptible to contamination arising from poor sources and exposure during haulage. The cans are not wash regularly and in some having greenish colour in them (Spirogyra).

\section{Price, coverage and continuity of water vending}

The pricing of water by vendors have no fixing body or established basis and is generally left to the individual vendor in the study area. The vendors, however, respond to 
Fig. 12 Types of water-borne diseases observed

Fig. 13 Variation in water prices per jerry-can during dry and rainy season
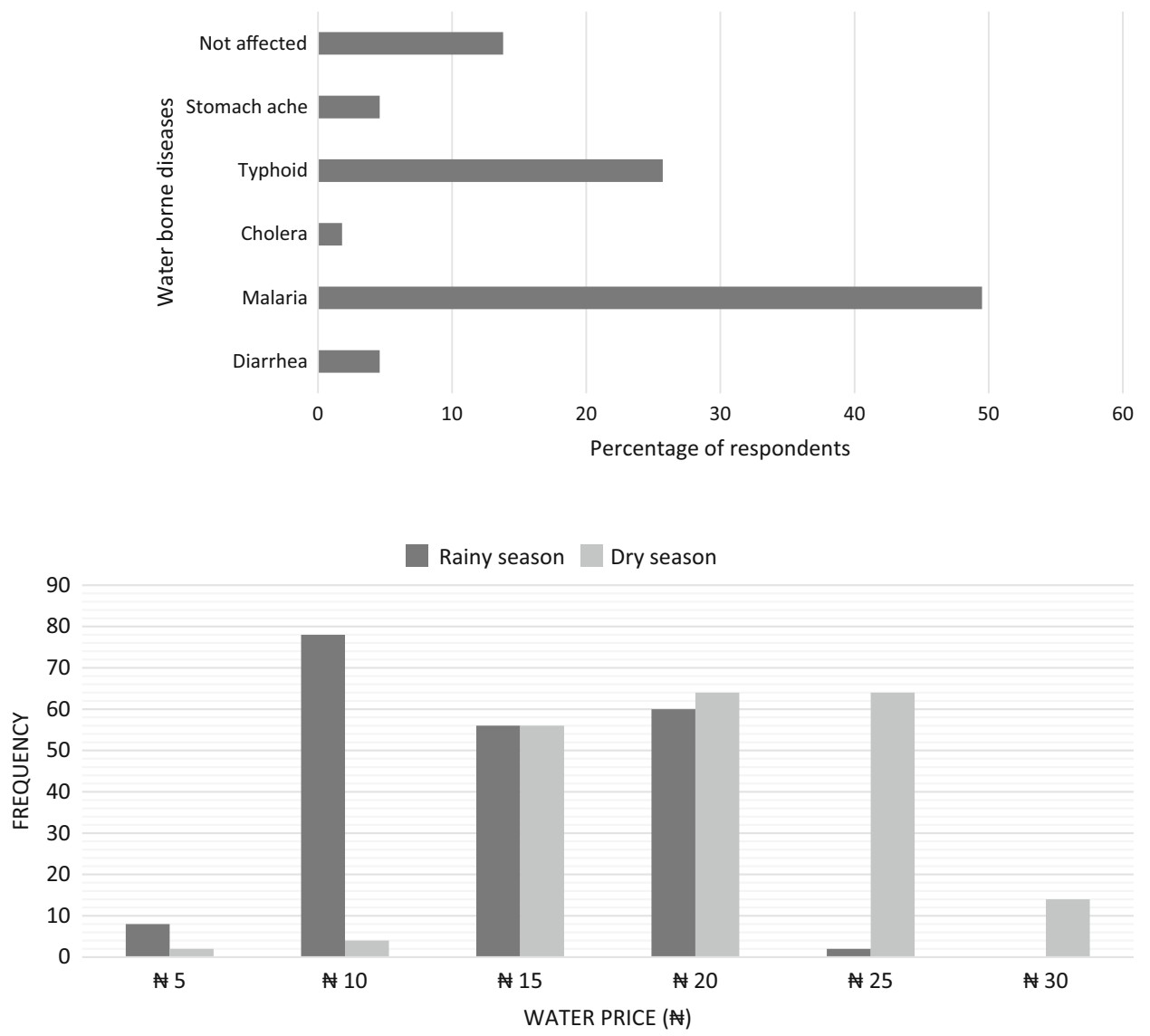

two elements; the demand for water at any given time and the distance between the water sources and delivery points. In periods of water shortages, prices are higher than at ordinary times. The retail water vendors pay $\$ 3-5$ per each jerry-can ( $\$ 60$ per 12 or $\$ 100$ per 20 jerry-cans pushcart). In the case of the hand-dug wells, each well has an average of 4 vendors on daily basis that pay a fixed rate of $\$ 100$ and draw as much water as they can. Thus, each well can have a fixed rate of $\$ 400$ every day. The maintenance of the well is carried out by the well owner to ensure continuity.

The average price during dry season is 20.08 (\$0.07) with a standard deviation of 4.97 . The lowest price was N10 within $100 \mathrm{~m}$ or so, for example, in places like Gobirawa and the highest price was $\$ 30$ (\$0.1) (which is the peak) in areas around Kabuwaya and Kantudu that are farthest away from the sources. During rainy season, the average price was $\$ 14.02$ (approximated to 15 because coins are not being circulated nowadays) with a standard deviation of 4.20 . The lowest price was $\$ 5$ (or $\$ 10$ for 3 jerry-cans in places like Dandinshe) and the highest was $\$ 20$ (which is the peak) in faraway areas around Madabo and Kabuwaya. The price was low because during rainy season households have enough water they harvest and so the demand is low and consequently the price. Figure 13 indicates variation in water prices per jerry-can according to distance from the water kiosk during rainy and dry season. Households in the studied wards are already paying more for water. Comparing the average fixed tariff set by KNSWB of 20 or $\$ 0.07 / \mathrm{m}^{3}$ for domestic supply (Parkman 2000) with $\$ 560$ or $1.84 / \mathrm{m}^{3}$ in rainy season and $\$ 800$ or $\$ 2.62 / \mathrm{m}^{3}$ in dry season, it implied that the price of vended water is almost 28 and 40 times that of a household pipe-water connection during dry season and rainy season, respectively.

The volume of sales is difficult to assess but a typical vendor can have a net sale of 720 per day (3 trips with 12 jerry-cans pushcart). Renting the pushcart at 100 per day will make a net earnings of $\$ 620$. Working seven days per week, that is $\$ 4340$. Allowing for weekly maintenance of the pushcart (repairs tend to be made by vendors regardless of who owns it) some 200 . Four times that is 16,560 , which is a bit less than the current minimum wage of $\$ 18,000$ (\$59) but higher than the average monthly income of $\$ 9750$ (\$32).

In terms of continuity water vending will continue to grow as long as there is lack of supply or intermittent supply (irregular, inefficient and inadequate) from KNSWB (Parkman 2000) which is obvious at present, coupled with the rapid population increase in Kano, about 
$3.36 \%$ growth rate (National Population CommissionNPC 2010). These are indications that the market potential for this system is assured. Another point is that the individual/household-based nature of water vending system presents a simple process without unnecessary institutional difficulties. The entire relationship is based on pure economic relationship of demand and supply and once households are supplied, the system is assured of its continuity. The consumers, nevertheless, have problems with the waiting time of more than $2 \mathrm{~h}$ which they consider very long and in some places have to travel a distance of more than $500 \mathrm{~m}$ before getting the water vendor.

\section{Willingness-to-pay (WTP) for water supply from KNSWB}

Willingness-to-pay for improved water supply was elicited in the study area and in-house connection from KNSWB seems to the feasible option that respondents are happy with even though the supply is not $24 \mathrm{~h} 7$ days. Most of the boreholes constructed by politicians as constituency projects have failed because of over exploitation of the

Table 2 Willingness-to-pay amounts for in-house connection from KNSWB

\begin{tabular}{lll}
\hline Monthly rate (N) & Frequency $(f)$ & $\begin{array}{l}\text { Percentage } \\
\text { frequency }(\% f)\end{array}$ \\
\hline $0-100$ & 26 & 12 \\
$101-200$ & 20 & 12 \\
$201-300$ & 28 & 13 \\
$301-400$ & 14 & 6 \\
$401-500$ & 88 & 38 \\
$501-600$ & 32 & 15 \\
$601+$ & 10 & 5 \\
\hline
\end{tabular}

groundwater especially during dry season and poor management. No spring or river (protected stream) was available that could be used as an option in the area. It was revealed that $88 \%$ of the respondents said they would like to use in-house connection, while only $12 \%$ said they would not like this option and would not like to pay anything. Those people who want to pay expressed the view that they are currently willing to pay an average of $\$ 367$ (\$1.19) (standard deviation $=$ 172). Table 2 shows the amounts of money respondents indicated they are willing to pay as tariff for private in-house water connection from KNSWB. Although the amounts indicated reflects only $4 \%$ of their monthly incomes-it is a big share considering their household size to cater for-the amount is still lower than what they spend on vended water ( $\$ 0.8$ per liter). KNSWB collects $\$ 500$ (\$1.64) for house with no soak away and $\$ 800$ (\$2.62) for the houses with soak away even though the supply is intermittent. Some of the responses indicated unwillingness to pay any amount while few indicated paying large sums of money. $12 \%$ indicated they are willing to pay 100 ( $\$ 0.33$ ) or less, this amount is very low because they normally fetch water from public boreholes and they have small households and therefor the money they spend on water is minimal. Also, low income (poor) households buy as little as they must and only after having exhausted all the free sources, such as water from wells and boreholes. Mostly adults and children spend a lot of time queuing to fetch water as it can be seen in Fig. 14 and thus their WTP is very low. Generally, most respondents perceived water to be social goods that must be provided by Authorities. Water and electricity is still a subject of campaign by politicians in the study area. Only $5 \%$ are WTP for above $\$ 600$ (\$1.97), this could be due to the level of their income and the distance of the water sources.

Fig. 14 Children and adults queuing at public borehole

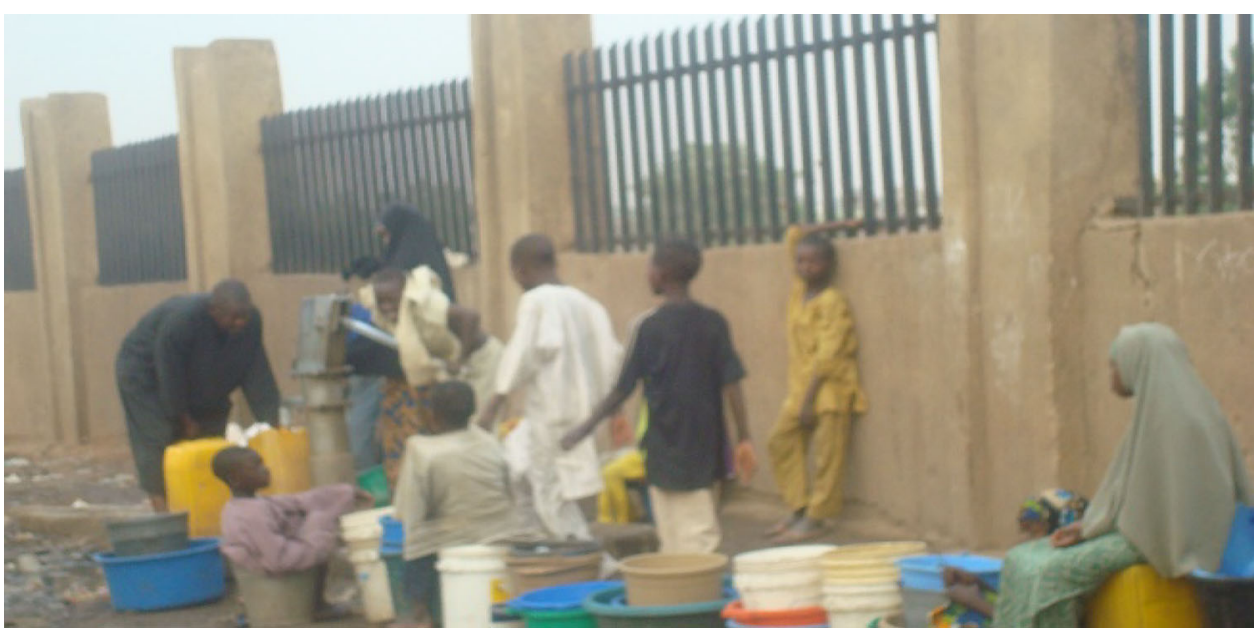




\section{Conclusions}

The role of water vendors in water service delivery has been accepted as an alternative source of water in the five wards studied, instead of an interim solution, and it is extending coverage and is unlikely to change so long as supply from Kano State Water Board remains status quo. Despite the greatest concern for quality their activities are not monitored by the authority and hence some prevalence of water-related diseases. Results show that market for vended water exists even during rainy season. The price differs in different wards due to proximity of the sources (ease or difficulty by which vendors can get water) and seasons. Households are already paying more for water because the price of vended water is almost 28 and 40 times that of in-house connection from KNSWB during rainy and dry season, respectively. The willingness-to-pay shows that people are willing to pay amount lower than the present tariff set by the Kano State Water Board largely due to their perception of water as social goods to be provided by government.

The study suggests designing and implementing effective policy and intervention initiatives that will support water vending and integrate it into mainstream water supply system in form of public private partnership (PPP). Furthermore, KNSWB would need to review its billing system to cover for the full costs of supply so that consumers would receive more and safer water at a lower price. It also recommends changing people's perception on water by enlightening and education. Further research should focus on estimating the total volume of water supplied and sale by water vendors.

Acknowledgements The author thanks the reviewers for their helpful comments, and appreciates the professionalism shown by the editor-in-chief and the efforts of enumerators that helped in the survey.

Open Access This article is distributed under the terms of the Creative Commons Attribution 4.0 International License (http://crea tivecommons.org/licenses/by/4.0/), which permits unrestricted use, distribution, and reproduction in any medium, provided you give appropriate credit to the original author(s) and the source, provide a link to the Creative Commons license, and indicate if changes were made.

\section{References}

Abubakar IR (2016) Quality dimensions of public water services in Abuja, Nigeria. Util Policy 38:43-51

Acey C (2008) Neighbourhood effects and household responses to water supply problems in Nigerian cities. J Transdiscipl Res South Afr 4(1):123-156

Ayalew M, Chenoweth J, Malcolm R, Mulugetta Y, Okotto LG, Pedley S (2014) Small independent water providers: their position in the regulatory framework for the supply of water in
Kenya and Ethiopia. J Environ Law 26:105-128. doi:10.1093/ jel/eqt028

Dauda SA, Yacob MR, Radam A (2015) Household's willingness to pay for heterogeneous attributes of drinking water quality and services improvement: an application of choice experiment. Appl Water Sci 5:253-259. doi:10.1007/s13201-014-0186-6

Galvin R (2015) How many interviews are enough? J Build Eng 1:212

Hutin Y, Luby S, Paquet C (2003) A large cholera outbreak in Kano City, Nigeria: the importance of hand washing with soap and dangers of street-vended water. J Water Health 1(1):45-52

Ishaku HT, Peters AA, Haruna A, Dama FM (2010) the role of private water vending in Nigerian peri-urban informal settlements: implication for policy makers. J Water Resour Prot 2:10821087. doi:10.4236/jwarp.2010.212127

Kjellen M (2000) Complementary water systems in Dar es Salaam, Tanzania: the case of water vending. Int J Water Resour Dev 16 (1):143-154. doi:10.1080/07900620048626

Kjellen M, McGranahan G (2006) Informal water vendors and the urban poor. International Institute for Environment and Development (IIED), UK

McGranahan G, Njiru C, Albu M, Smith M, Miltin D (2006) How small water enterprises can contribute to the Millennium Development Goals. Evidence from Dar es Salaam, Nairobi, Khartoum and Accra. Water, Engineering and Development Centre, Loughborough University, UK

National Population Commission (NPC) [Nigeria] and ICF International (2014) Nigeria Demographic and Health Survey 2013. NPC and ICF International, Abuja, Nigeria, and Rockville, Maryland, USA

Nigerian Industrial Standard (2007) Nigerian standard for drinking water quality (NIS 554: 2007). Standards Organisation of Nigeria, Abuja

Njiru C (2004) Utility-small water enterprise partnerships: serving informal urban settlements in Africa. Water Policy 6(5):443-452

Nnaji CC, Eluwa C, Nwoji C (2013) Dynamics of domestic water supply and consumption in a semi-urban Nigerian city. Habitat Int 40:127-135

NPC (2010) 2006 Population and Housing Census of the Federal Republic of Nigeria: Housing Characteristics and Amenities, Priority Tables (LGA), vol II. National Population Commission, Abuja

Olajuyigbe AE, Rotowa OO, Adewumi IJ (2012) Water vending in Nigeria- a case study of Festac Town, Lagos. Nigeria. Mediterr J Soc Sci 3(1):229-239. doi:10.5901/mjss.2012.03.01.229

Olofin EA (1987) Some aspects of physical geography of Kano region and related human responses. B.U.K. Debis Standard Printers, Kano

Onyenechere CO, Eleazu EI, Azuwike OD, Osuji S, Igwe CF (2012) The dynamics of domestic water vending in Enugu North L.G.A. of Enugu State, Nigeria. J Water Resour Prot 4:224-230. doi:10. 4236/jwarp.2012.44025

Opryszko MC, Huang H, Soderlund K, Schwab KJ (2009) Data gaps in evidence-based research on small water enterprises in developing countries. J Water Health 7(4):609-622

Parkman Nig. Ltd. (2000) Greater Kano water feasibility study. Final report volume 1 -main report

Rahaman MM, Ahmed TS (2016) Affordable water pricing for slums dwellers in Dhaka Metropolitan Area: the case of three slums. J Water Resour Eng Manag 3(1):15-33

Sansom K, Bos A (2008) Utility and non-state water service provision for the urban poor. Int J Water 4(3/4):290-303

Sheshe MU, Magashi AM (2014) Assessment of physicochemical quality of sachet water produced in selected local government areas of Kano Metropolis, Kano State, Nigeria. Bayero J Pure Appl Sci 7(2):31-35 
Snell S (1998) Water and sanitation services for the urban poor. Small-scale providers: typology and profiles. Water and Sanitation Program, World Bank, Washington DC

van Dijk MP (2008) Role of small-scale independent providers in water and sanitation. Int J Water 4(3/4):275-289

Whittington D, Lauria DT, Mu X (1991) A study of water vending and willingness to pay for water in Onitsha, Nigeria. World Dev 19(2/3):179-198

WHO, UNICEF (2015) Progress on sanitation and drinking water2015 update and MDG assessment. World Health Organisation, Geneva
Wutich A, Brewis A (2014) Food, water, and scarcity: toward a broader anthropology of resource insecurity. Curr Anthropol 55 (4):444-468

Wutich A, Beresford M, Carvajal C (2016) Can informal water vendors deliver on the promise of a human right to water? Results from Cochabamba, Bolivia. World Dev 79:14-24. doi:10.1016/j.worlddev.2015.10.043

Zaroff B, Okun DA (1984) Water vending in developing countries. Aqua 5:289-295 